\title{
Who's bad: as representações de Michael Jackson na revista Veja
}

\section{Renné Oliveira França}

\section{Resumo}

0 trabalho busca uma aplicação do conceito de representação na transformação da figura de Michael Jackson ao longo dos anos a partir da revista Veja. Representação será tratada segundo Stuart Hall, como encontro entre significados e linguagem em uma cultura, e a revista será percebida como local onde os sentidos compartilhados em uma sociedade são representados. Para tal, foram observadas as quatro revistas em que 0 cantor apareceu na capa e como a escolha de imagens e palavras revela valores e produz discursos a seu respeito.

\section{Palavras-chave}

Representação. Jornalismo. Revista. Michael Jackson.
Renné Oliveira França | renneof@gmail.com

Doutorando do Programa de Pós-Graduação em Comunicação Social da Universidade Federal de Minas Gerais - UFMG, mestre em Comunicação Social pela UFMG. Bolsista da CAPES, pesquisador do Grupo de Pesquisa em Imagem e Sociabilidade - GRIS (www.fafich.ufmg.br/gris).

\section{Introdução}

Sobre um fundo escuro, uma luva branca brilha como uma joia. Reproduzindo uma mão em posição horizontal, com o dedo indicador esticado e cravejada de diamantes, a luva paira sobre um bracelete dourado, que completa o conjunto como a base de uma coroa prateada. Acima, com as letras vazadas em contorno amarelo-ouro está 0 nome Veja. Abaixo, em discretas letras brancas, o nome do rei que ostenta a coroa simulada: Michael Jackson. 0 "rei do pop" dominou as capas dos principais jornais e revistas logo após sua morte em 25 de junho de 2009. Enquanto outras publicações buscaram imagens do corpo e rosto do cantor, Veja optou por uma luva para representar Jackson. Por quê?

0 objetivo desse artigo é olhar para as representações de Michael Jackson ao longo dos anos a partir da revista Veja. Poucos artistas se transformaram tanto quanto a criança do "Jackson 5", e a mídia atuou como principal articuladora da modificação das representações do cantor, que de menino prodígio se tornou o maior vendedor de discos da história e foi acusado de pedofilia, 
além de passar por uma transformação física surpreendente. Quem é Michael Jackson a partir da Veja? Que valores sua imagem carrega? Como as representações da revista se transformaram ao longo dos anos para culminar em uma luva brilhando em um fundo preto?

Representação será aqui tratada, a partir das discussões de Stuart Hall (1997), como local de encontro entre significados e linguagem em uma cultura. A revista Veja será percebida, então, como local onde signos e imagens representam sentidos compartilhados em uma sociedade, ao mesmo tempo em que atualiza ou modifica esses significados. 0 recorte para análise foi estabelecido a partir das capas que a revista dedicou ao cantor ao longo de toda a sua carreira: julho de 1984, outubro de 1993, fevereiro de 1996 e julho de 2009.

Veja surgiu em 1968, mesmo ano da formação do "Jackson 5", que viria a lançar seu primeiro disco em 1971, quando Michael Jackson tinha apenas 12 anos. 0 grupo formado por cinco irmãos conquistou grande sucesso de público e se desfez quando o cantor partiu para a carreira solo no final da década de 70. Já cantando sozinho, Jackson atingiu o auge com 0 álbum "Thriller", em 1982, até hoje o disco de maior sucesso de todos os tempos, com mais de cem milhões de cópias vendidas. Em 1984, já como maior astro do planeta, e com o título de rei do pop, o cantor iniciou uma ambiciosa turnê de shows, tema de sua primeira capa de Veja.
Apesar de continuar criando sucessos, Jackson não conseguiu repetir o feito de "Thriller", e suas excentricidades na vida pessoal acabaram por chamar mais atenção da mídia do que seus feitos artísticos. 0 estranho embranquecimento de sua pele, os videoclipes cada vez mais grandiosos e 0 recorde mundial de público de sua turnê "HIStory" dominaram os noticiários no início dos anos 90, e Veja deu sua segunda capa ao cantor quando ele trouxe seu grandioso show ao Brasil em 1993. Nos anos 90 também surgiram as denúncias de pedofilia, quando Jordan Chandler, de 13 anos, o acusou de abuso sexual. Em meio ao escândalo, Jackson casou com Lisa Marie Presley (para se divorciar dois anos depois) e depois com Deborah Rowe (com quem teve dois filhos) e veio ao Brasil em 1996 gravar o clipe da música "They don't care about us" no Morro Santa Marta (RJ) e no Pelourinho (BA), o que lhe rendeu sua terceira capa de Veja. Nos anos 2000, o cantor desentendeu-se com sua gravadora (Sony), teve um terceiro filho (de mãe anônima), foi eleito "Cantor do Milênio" no World Music Award e ganhou mais uma acusação de abuso sexual, agora por Gavin Arvizo, sendo inocentado por falta de provas e pela declaração do psiquiatra Stan Katz de que Jackson tinha a mente de uma criança. Envolto em dívidas, ele ensaiava para a série de concertos "This is it", que teria início em 13 de julho de 2009, quando teve uma parada cardíaca e morreu em circunstâncias ainda não esclarecidas. Michael Jackson recebeu, então, sua última capa de Veja. 


\section{Representando Michael}

Segundo Stuart Hall (1997), cultura é

compartilhamento de significados, e é na

linguagem onde esses significados são produzidos

e trocados que damos sentido às coisas. Buscando

perceber como a linguagem constrói significados, ele a compreende como um sistema de representação no qual usamos signos e símbolos para representar para os outros nossos conceitos, ideias e sentimentos. Linguagem seria, então, um dos meios pelos quais pensamentos e valores são representados na cultura. Entendendo a cultura como sentimentos, emoções e ideias, podemos pensar os significados culturais como aquilo que organiza e regula praticas sociais, influenciando nossas condutas e tendo como consequência efeitos reais e práticos.

As coisas em si não possuem um significado único, fixo e imutável: são os sujeitos participantes na cultura que dão significados aos objetos, pessoas e acontecimentos. É pelo nosso uso das coisas (o que dizemos, pensamos e sentimos em relação a elas) que as representamos, e assim damos a elas significados. Usando a discussão de K. Woodward sobre cultura e identidade, Hall aponta o poder dos significados para nos dar um sentido de quem somos e onde pertencemos: significados estes produzidos e trocados em todas as interações sociais e pessoais das quais fazemos parte, incluindo, claro, a mídia. 0 que nos faz retornar à linguagem como sistema de representação.
A mídia, obviamente, opera através da linguagem, e é esta que promove a circulação e produção de significados. Isso é feito através de elementos como sons, palavras, gestos, expressões e até roupas que funcionam como símbolos que carregam significados, representando os sentidos que se pretende comunicar. Hall busca uma abordagem discursiva para a compreensão da representação, pois acredita que no discurso pode-se perceber não apenas como a linguagem e a representação produzem significado, mas também como um discurso particular conecta-se ao poder, regulando condutas e construindo identidades e subjetividades, definindo a maneira como certas coisas são representadas, pensadas e estudadas.

Olhando para a linguagem como local privilegiado para a percepção da representação e focado nas estruturas do discurso, Hall opta por um método de análise voltado para os textos como local de visualização dos sentidos que circulam pela cultura. Entretanto, ele está sempre atento para 0 contexto da produção desses textos, uma vez que entende que um estudo da representação só pode ser feito tendo em mente 0 sistema cultural e social em que o significado simbólico circula (ou circulou). Isso porque a representação funciona menos como um modelo de um único transmissor, mas mais como um diálogo, sempre em uma interação dos lados do processo comunicativo: 0 significado vai sempre depender da relação das coisas com o mundo. É dessa relação dialógica que surge a representação, e é graças a esse processo interativo (que depende de códigos 


\section{¿ecompós}

www.e-compos.org,br

| E-ISSN 1808-2599 |

culturais comuns) que não podemos nunca ter a

garantia de que uma representação se manterá estável para sempre.

A representação de Michael Jackson pela

revista Veja se transformou com o passar do

tempo, provando-se como diálogo contínuo que

compartilha significados dentro de uma mesma

cultura, e instável devido à trajetória pessoal

do cantor, às transformações da sociedade e às

mudanças da própria revista enquanto detentora

de linguagem.

\subsection{0 astro}

Na capa da revista Veja de 18 de julho de 1984,

Michael Jackson aparece cantando. Trata-se

da única, entre todas as capas, com o cantor.

Apresenta-0 "em ação", fazendo a atividade

que 0 tornou famoso. Sobre um fundo preto,

que destaca ainda mais sua imagem reluzente, Jackson aparece "brilhando", com reflexos luminosos em seus cabelos, rosto e paletó.

Brilha como 0 astro que a manchete dá nome:

Michael/Jackson 0 ASTRO/TOTAL.

Figura 1: Capa de Veja em 18 de julho de 1984.

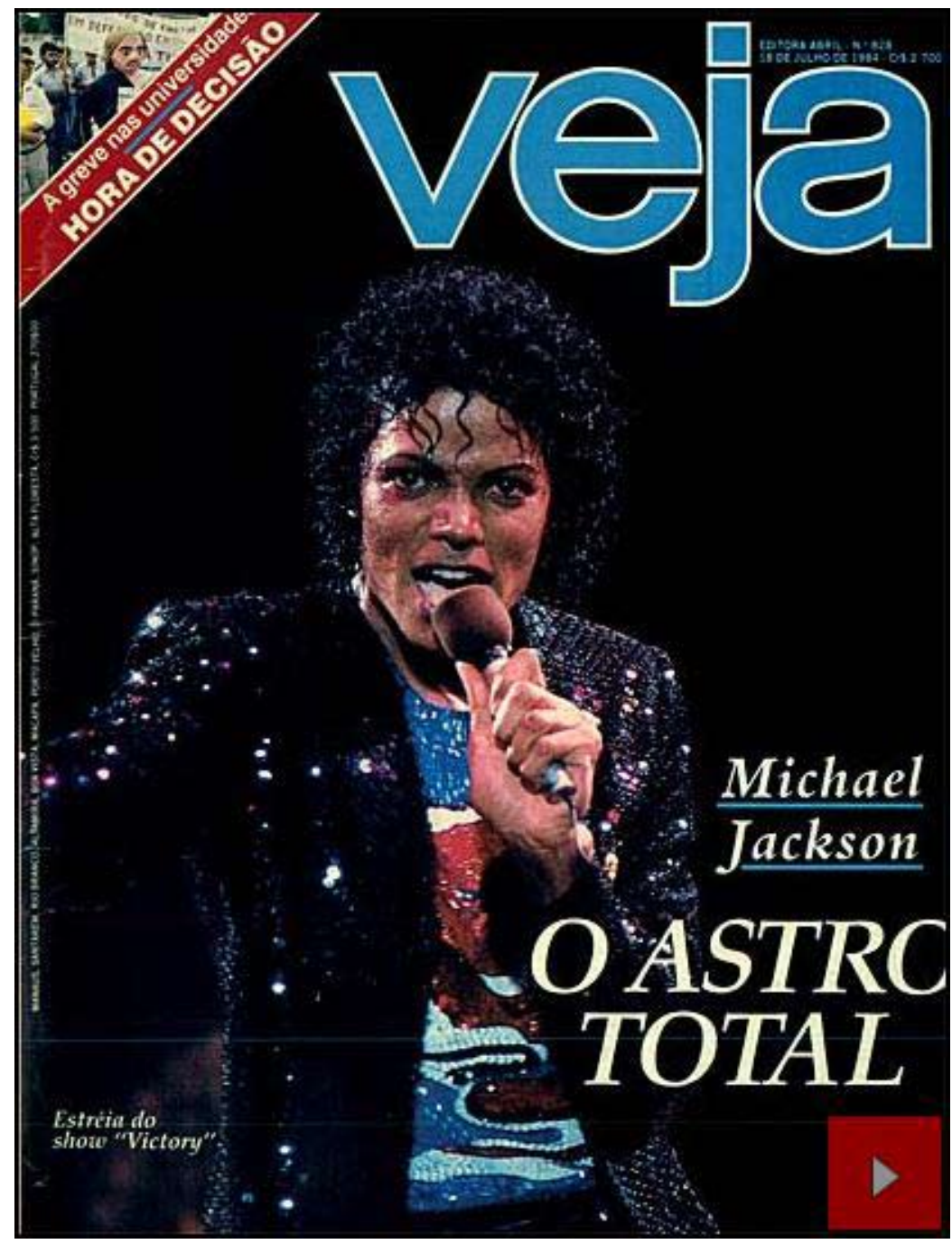


0 título Veja está em azul, mesma cor que sublinha o nome do cantor, como se a revista ratificasse a posição de Michael Jackson como 0 mais importante artista da época.

A representação do cantor na capa tem um sentido duplicado, fazendo uso da linguagem em seu caráter conotativo e denotativo. Precisamos lembrar que o significado é construído no sistema de representação, mas é no código que se torna fixo, estabilizando-se dentro de diferentes linguagens e culturas; e o signo é sempre lido a partir de um significante que faz referência a um significado (SAUSSURE, 1997). Assim, a interpretação é parte essencial para o processo de significação, uma vez que todo significante precisa ser decodificado pelo receptor. Apesar de o próprio Hall apontar falhas neste modelo por focar apenas nas formas (especialmente na linguagem), não entrando em uma discussão de poder, historicidade e cultura, o trabalho de Saussure é importante por mostrar a representação como prática discursiva, e a semiótica surge como uma ferramenta de análise das representações. 0 trabalho de Roland Barthes (1978) em Mitologias aparece como uma aplicação do modelo de Saussure aos discursos da mídia, buscando uma tentativa de desnaturalização de certos produtos, pessoas e acontecimentos, e de importante auxílio nessa análise da representação de Michael Jackson.

Barthes propõe a análise de certas imagens e discursos chamando a atenção para os sentidos que surgem ambíguos, sempre carregados de mais de um significado. Ele chama de mito esses signos recebidos como uma verdade inquestionável, mas que na realidade seriam uma forma, sistemas de significação que produzem um sentido no qual significante e significado são ambos manifestos (o significado não se "esconde" atrás do significante, ambos estão presentes). Por isso, Barthes chama a atenção para os aspectos denotativos e conotativos de todas as imagens, buscando, ainda, o significado privilegiado no discurso, que normalmente se dá pela conjunção da imagem com um texto.

Na capa de Veja, o sentido denotativo está na figura do jovem negro que segura um microfone: ele é Michael Jackson (o texto ao lado da imagem deixa isso claro), um cantor provavelmente em um show. Já o fundo escuro e a luz que paira sobre a imagem de Jackson trazem um sentido conotativo do ser especial, da estrela que brilha sozinha na escuridão. Sentido esse que se revela privilegiado na revista pela associação da imagem com a manchete 0 ASTR0/TOTAL. Os olhos de Jackson estão no centro visual da página: o "V" do título Veja, direciona o olhar para baixo (em conjunto com a perna do "j"), enquanto o microfone em punho aponta para cima, confluindo o foco nos olhos que encaram o leitor. 0 olhar fixo de Jackson "abre" a leitura da capa, reforçando sua posição imponente, de alguém capaz de encarar qualquer um, com um brilho superior às outras pessoas. 


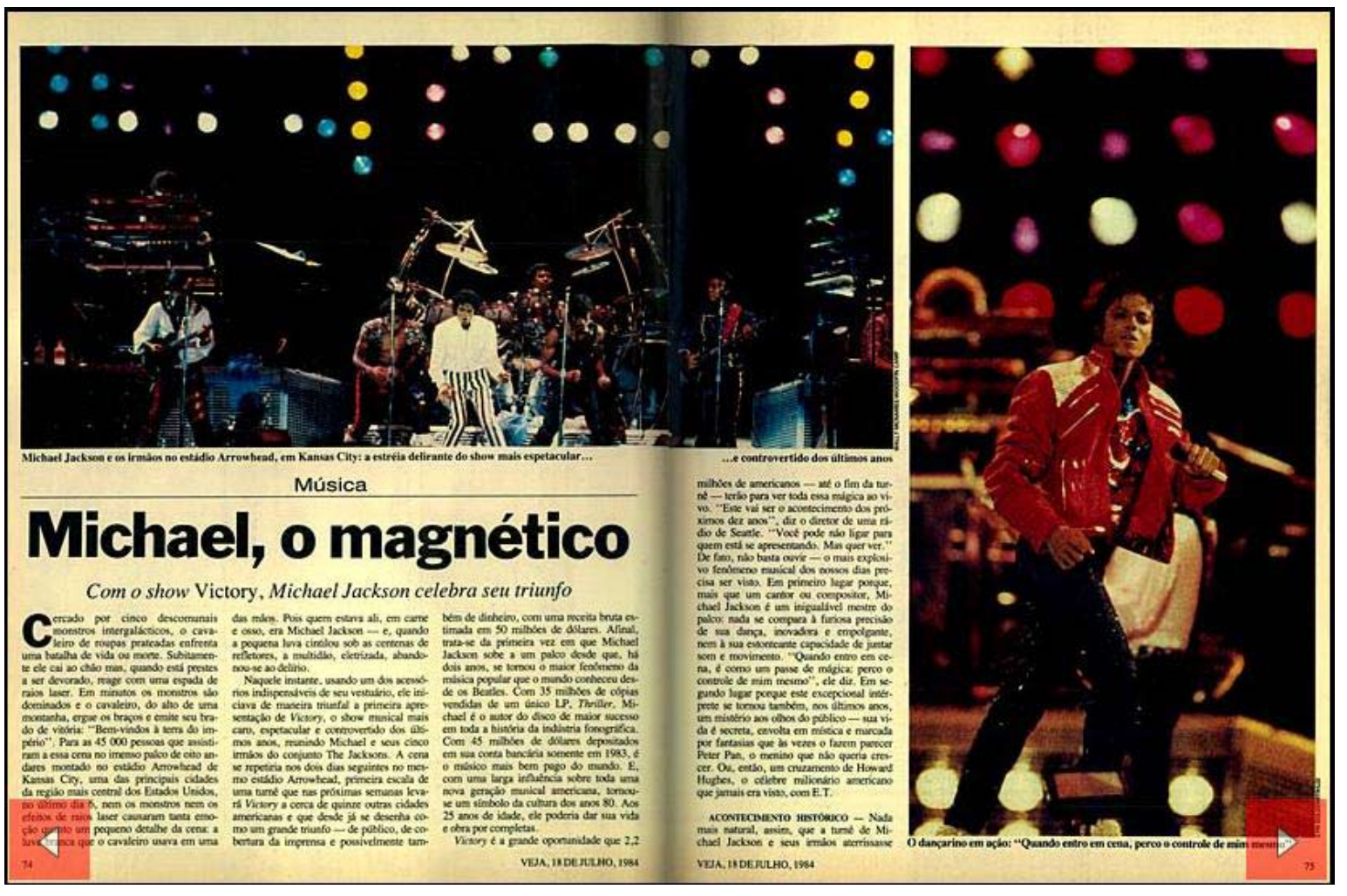

A matéria de capa continua a reforçar esse significado, representando Jackson como um talento extraordinário, uma pessoa especial. 0 título da reportagem, "Michael, o magnético", reforça a força magnetizante de seu olhar na capa e seu poder frente ao público, ilustrado com imagens dele dançando e cantando no palco.

A matéria abre com uma descrição de seu show "Victory": um cavaleiro de roupas prateadas enfrenta monstros de outros planetas e os vence com uma espada laser. 0 cavaleiro é Michael Jackson, e a escolha da revista em começar a matéria dessa maneira reforça sua representação de ser super-humano, herói com poderes especiais. Interessante perceber como
Veja chama atenção para a maneira como a

plateia reconhece 0 cantor apesar da fantasia de cavaleiro: pela sua luva prateada, a mesma que a revista irá usar para representá-lo na edição de sua morte. "[...] Nem os monstros nem os efeitos de raio laser causaram tanta comoção quanto um pequeno detalhe da cena: a luva branca que o cavaleiro usava em uma das mãos", conforme pode ser observado no detalhe abaixo.

As páginas seguintes continuam com a exaltação dos talentos do cantor e da magnitude de seu show, tratado como um "acontecimento histórico". Além de talentoso, Michael Jackson é apresentado como alguém capaz de produzir muita riqueza, $\mathrm{e}$ isso é mostrado a partir de dados numéricos de 


\section{Com o show Victory, Michael Jackson ce}

C ercado por cinco descomunais monstros intergalácticos, o cavaleiro de roupas prateadas enfrenta uma batalha de vida ou morte. Subitamente ele cai ao chão mas, quando está prestes a ser devorado, reage com uma espada de raios laser. Em minutos os monstros são dominados e o cavaleiro, do alto de uma montanha, ergue os braços e emite seu brado de vitória: "Bem-vindos à terra do império". Para as 45000 pessoas que assistiram a essa cena no imenso palco de oito andares montado no estádio Arrowhead de Kansas City, uma das principais cidades da região mais central dos Estados Unidos, no último dia 6 , nem os monstros nem os efeitos de raios laser causaram tanta emoção quanto um pequeno detalhe da cena: a luva branca que o cavaleiro usava em uma das mãos. Pois quem estava ali, em carne e osso, era Michael Jackson - e, quando a pequena luva cintilou sob as centenas de refletores, a multidão, eletrizada, abandonou-se ao delírio.

Naquele instante, usando um dos acessórios indispensáveis de seu vestuário, ele iniciava de maneira triunfal a primeira apresentação de Victory, o show musical mais caro, espetacular e controvertido dos últimos anos, reunindo Michael e seus cinco irmãos do conjunto The Jacksons. A cena se repetiria nos dois dias seguintes no mesmo estádio Arrowhead, primeira escala de uma turnê que nas próximas semanas levará Victory a cerca de quinze outras cidades americanas e que desde já se desenha como um grande triunfo - de público, de cobertura da imprensa e possivelmente tam-

Por fim, seu caráter de único, apesar das cópias, é reforçado no fechamento da matéria, que apresenta uma foto dele dançando com a legenda "um inigualável mestre do palco" e um texto que encerra a reportagem dizendo que "com sua dança, sua timidez e seu carisma, Michael determinou novos padrões para boa parte dos jovens. [...] uma façanha ele conseguiu: reunir milhões de pessoas, em dezenas de países, na mais esfuziante celebração já promovida pela música popular". A representação de Michael Jackson em sua primeira capa de Veja não deixa dúvidas: tratase de um dos maiores artistas da história da música, um ser especial e único. 


\subsection{Brilho dividido}

Na capa da revista Veja de 06 de outubro de 1993, Michael Jackson não é mais o "astro total" que brilha sozinho. Dividindo as atenções com a cantora Madonna, ele aparece fisicamente diferente, com a pele branca, o nariz mais fino, cabelos caídos sobre o rosto. Seu rosto é dividido espelhadamente com 0 da cantora, e as letras "V" e "j" do nome Veja apontam nosso olhar igualmente para os dois. 0 foco das atenções, entretanto, não é nem Jackson nem mesmo Madonna, mas o texto que surge em amarelo entre os dois: 0 BRASIL/NA ROTA DOS/MEGASHOWS. A capa da revista não trata exatamente de dois astros e suas conquistas, mas dos shows que eles farão no Brasil.

A matéria faz comparações com outros shows no país, mas chama a atenção para o fato de que nunca dois astros como Madonna e Jackson estiveram ao alcance dos brasileiros.

Figura 4: capa de Veja, 06 de outubro de 1993.

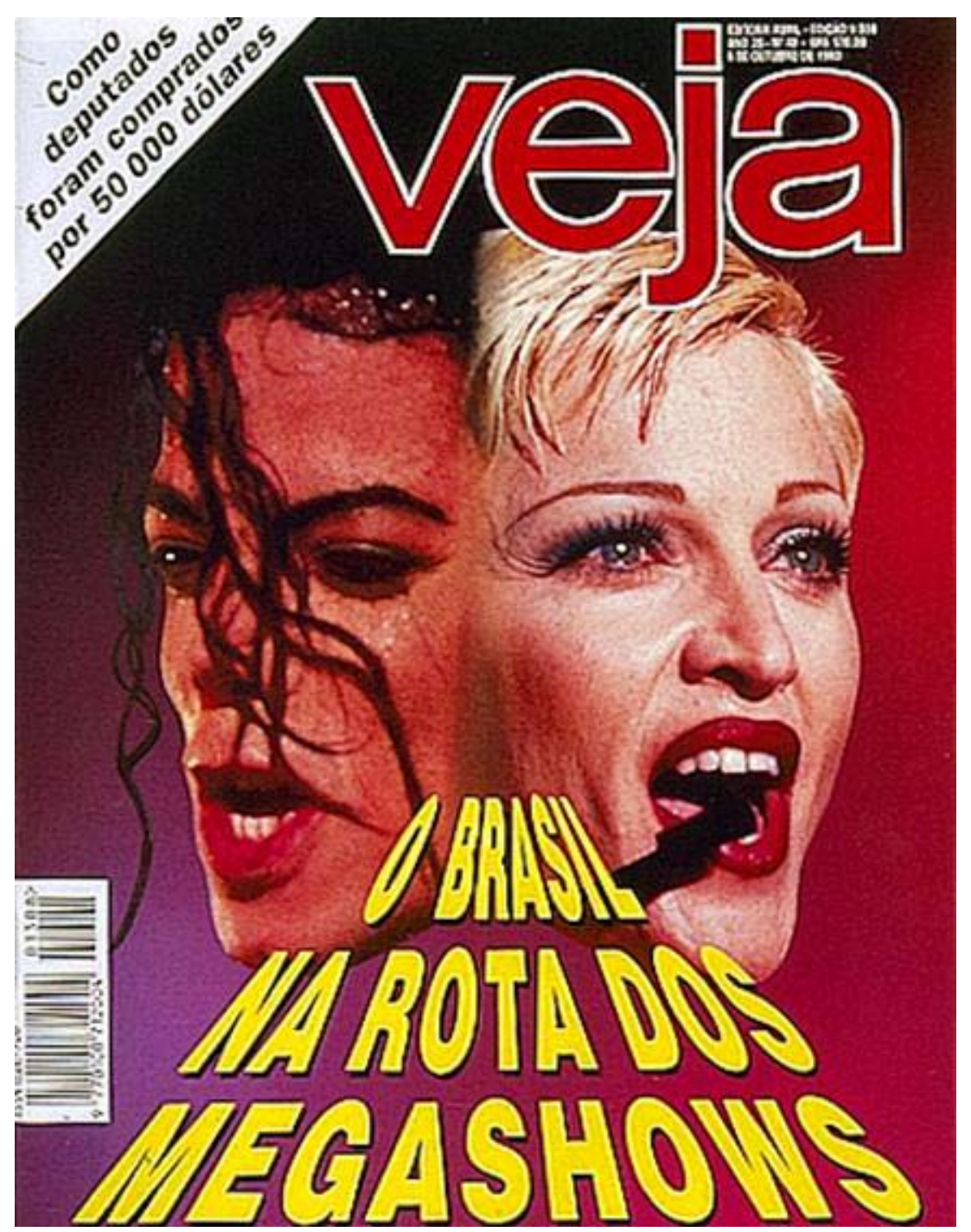


Figura 5: Edição de 06 de outubro de 1993 da revista Veja: páginas 116 e 117.

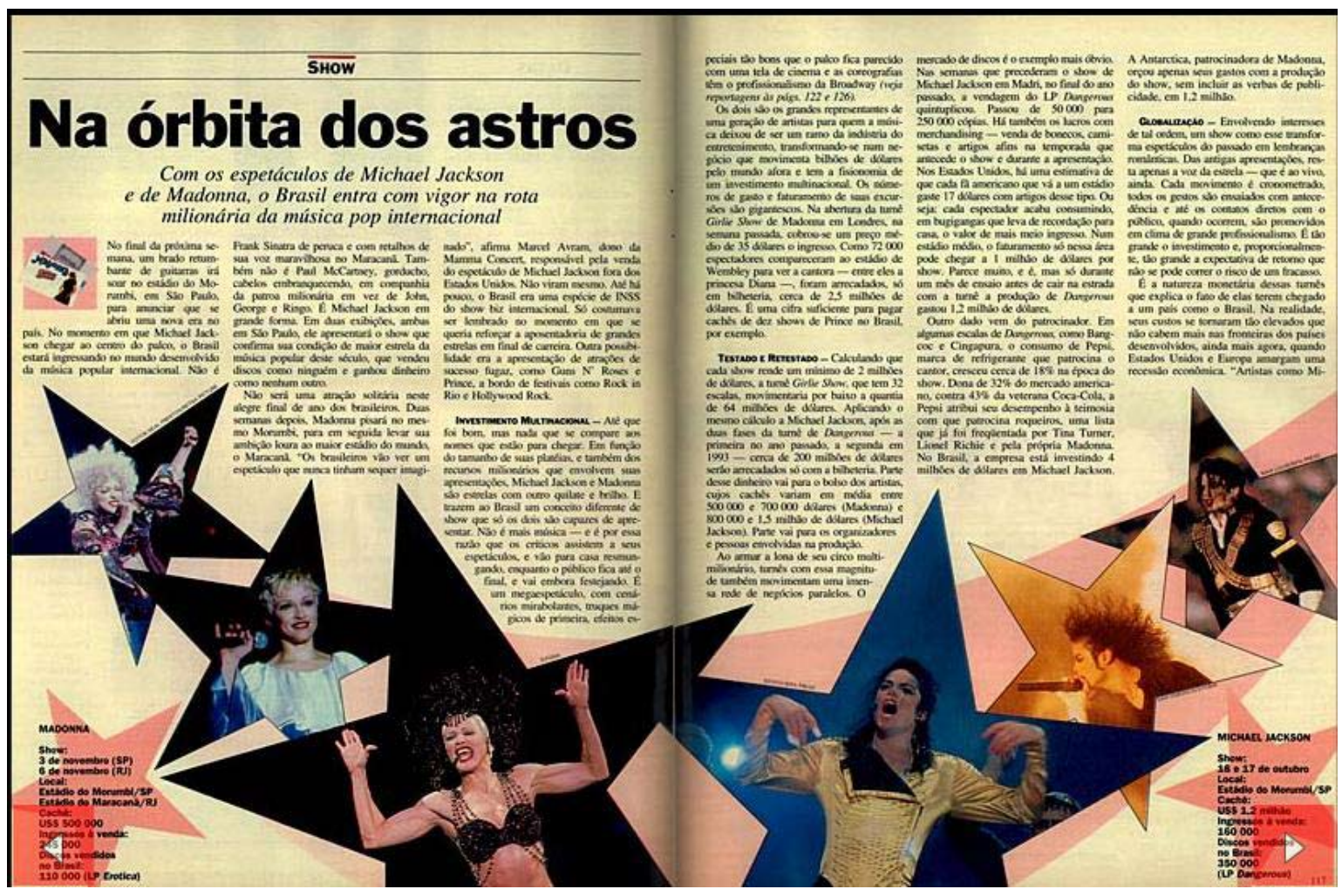

Michael Jackson é representado, então, como um dos dois maiores artistas do mundo, mas não mais 0 único. Isso é mostrado na arte das duas páginas que abrem a reportagem de capa e coloca imagens dos dois cantores dentro de estrelas: à esquerda, três estrelas mostram Madonna cantando em seus shows. À direita, de maneira espelhada, outras três estrelas mostram Jackson também cantando. A simetria entre as imagens revela o equilíbrio entre os dois astros, como se fossem equivalentes em talento, sucesso e dinheiro.

Trata-se de um exemplo de significação por opostos conforme tratada por Hall (1997) em sua problematização sobre a diferença em Representation. Utilizando as concepções de Saussure da linguagem, o autor busca compreender o significado pelo contraste: 0 preto, por exemplo, só ganharia sentido como oposto ao branco. Apesar de ser um modo reducionista para perceber o sentido, a significação por oposição pode ser interessante para 0 entendimento da representação de Jackson em Veja a partir de sua relação com Madonna.

A percepção que se tem de Michael Jackson só pode se estabelecer, na matéria, pela comparação com a cantora. Como a manchete aponta, Jackson continua sendo uma estrela, mas não mais única, revelado pelo plural em "astros". Sua personalidade é mostrada a partir das comparações com a cantora. Enquanto a Madonna é tratada como desinibida, Jackson é misterioso, e apresentado como um personagem 
de si mesmo: "Ele é mais um personagem do que um ser humano, pois não envelhece, não é negro nem branco e tem um tipo andrógino". Fica claro que na oposição com Madonna, Jackson é o estranho, o bizarro, em uma representação bastante diferente daquela mostrada na revista de 1984.

No parágrafo seguinte, a matéria toca pela única vez na denúncia de abuso sexual, reforçando suas características de pessoa estranha (ainda mais se comparado com a liberdade sexual "saudável" apresentada como uma das características de Madonna): "A polícia de Los Angeles investiga a denúncia de que ele teria abusado sexualmente de um menino de 13 anos". A utilização de uma única frase sobre 0 assunto revela a pouca importância dada ao caso na época, tratado mais como um boato. 0 que se pode perceber por essa edição de 1993 de Veja é um pouco da perda da força de Jackson enquanto astro (pois agora estaria no mesmo nível da Madonna) e o início de uma representação sua ligada às excentricidades, ao personagem que substitui o homem.

\subsection{0 excêntrico}

Michael Jackson retorna sozinho à capa de Veja em 14 de fevereiro de 1996, quando chega ao Brasil para gravar seu videoclipe da música "They don't care about us". Na imagem, Jackson faz um "v" com a mão direita (bem ao lado do "v" do título Veja) e seu braço erguido, em conjunto com o nome da revista e a manchete abaixo, criam um retângulo imaginário que é 0 foco do olhar. 0 rosto do cantor é 0 centro da atenção na capa, e ele está usando um chapéu e uma máscara sobre a boca e 0 nariz (atenção como o "j" de Veja aponta diretamente para sua máscara).

Retornando a Barthes (1978) e o duplo sentido nas imagens, Jackson não é aqui apenas um astro da música, mas também uma pessoa estranha, que usa uma máscara no rosto. 0 significado privilegiado é estabelecido pela manchete MICHAEL JACKSON/NO PAÍS/DO CARNAVAL. 0 sentido conotativo da capa está tanto na brincadeira entre máscara e carnaval, quanto na referência ao livro "Alice no País das Maravilhas". No primeiro caso, a ironia se estabelece pela figura estranha de Jackson sendo associada à ideia do Brasil como país do carnaval, muitas vezes entendido pelos estrangeiros como local do exótico, de pessoas fantasiadas, dançando nuas, lugar sem regras e leis. Já "Alice no País das Maravilhas" conta a história da garota que cai em um mundo estranho, bizarro, onde as regras da realidade não se aplicam, e ela encontra os mais insanos personagens, como, por exemplo, o Chapeleiro Maluco (e Jackson usa um chapéu na imagem). A representação do cantor aqui se volta para o louco, o exótico, o excêntrico. Jackson, mais do que um cantor, é apresentado como um personagem, pois não há na imagem nada que o remeta à sua música (não há microfone ou movimento da boca que indique que ele possa 


\section{¿ecompós}

www.e-compos.org,br

| E-ISSN 1808-2599 |

estar cantando). É apenas um homem estranho, usando uma máscara e um chapéu.

A noção de loucura continua na matéria de capa, intitulada "0 ridículo sururu pré carnavalesco". A chamada "Factoides sobem o morro e transformam o clipe de Michael Jackson num samba do crioulo doido" ganha um sentido diferente quando observada ao lado da imagem que se encontra à sua direita. Nela, Michael Jackson, de chapéu e máscara, acena enquanto desce de um avião com duas crianças, dando um significado conotativo à expressão "crioulo doido". Estaria a revista referindo-se apenas à confusão nas gravações do clipe ou também ao cantor?

Hall chama de intertextualidade a acumulação de significados na qual uma imagem faz referência à outra e tem seu significado alterado por ser lida no contexto de outras imagens.

0 verdadeiro sentido dependeria, então, de uma leitura da imagem em relação a outras.

Figura 6: Capa Veja, 14 de fevereiro de 1996

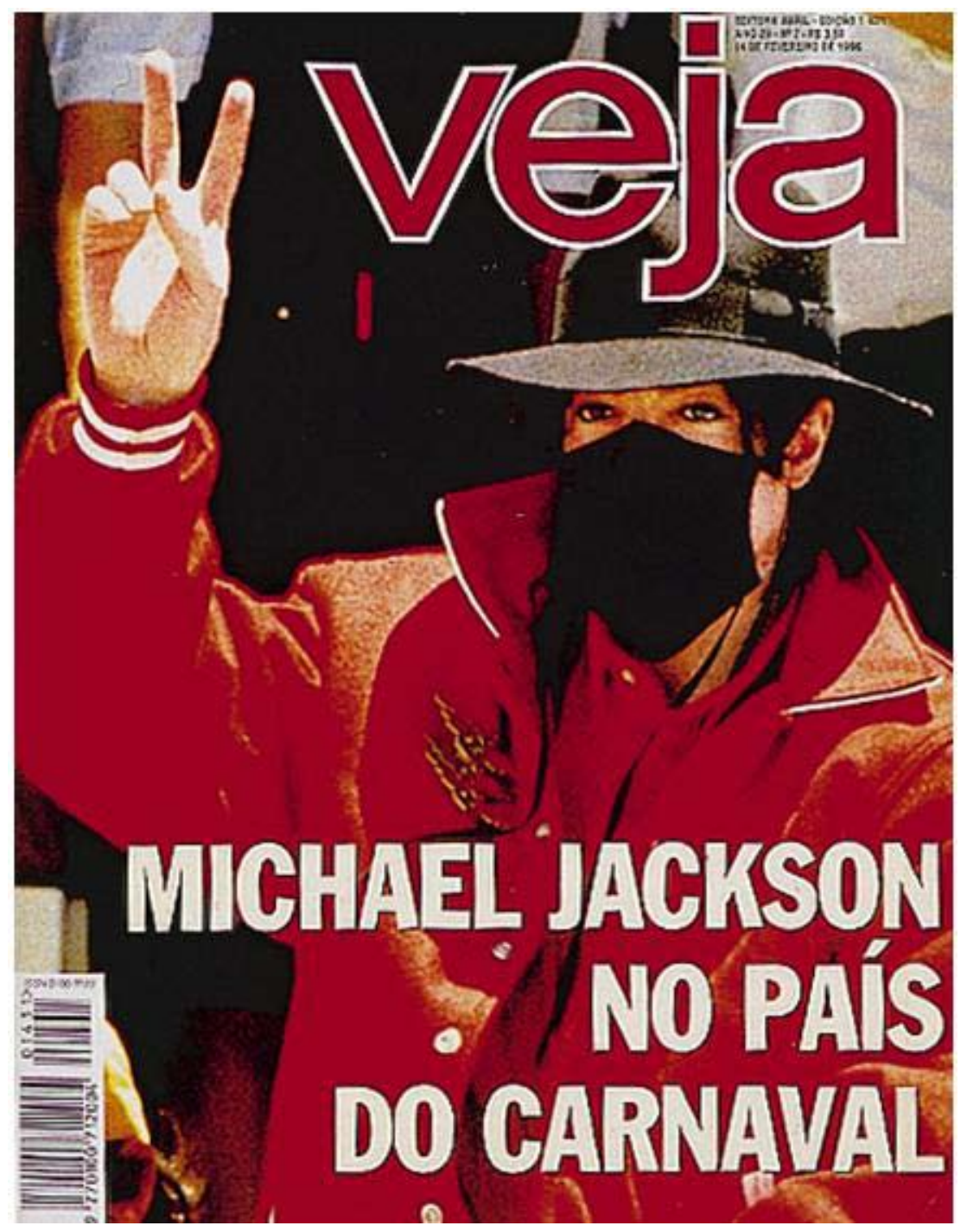


Figura 7: Edição de Veja de 14 de fevereiro de 1996, páginas 34 e 35.

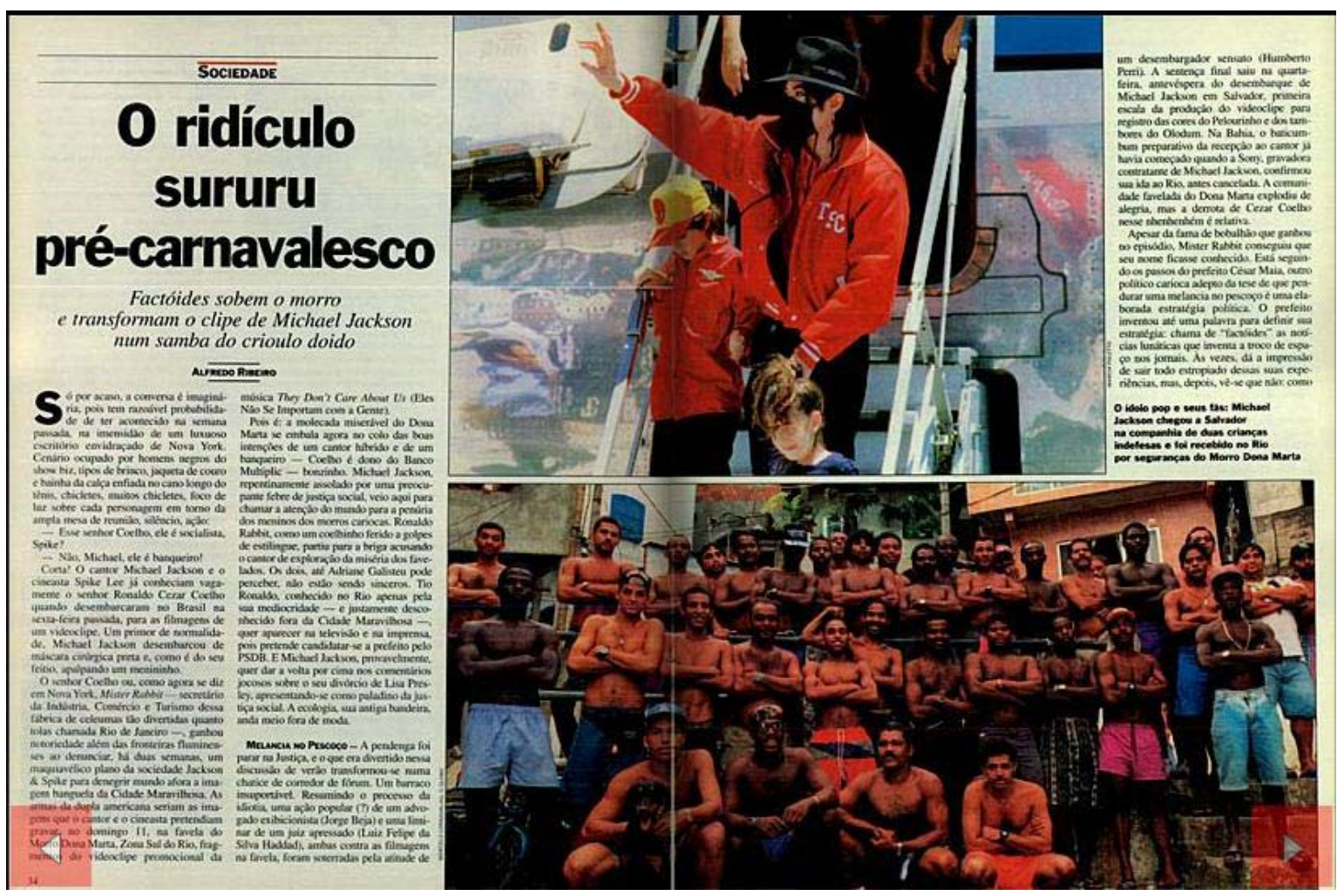

A representação de Michael Jackson como

estranho pode ser percebida, então, na maneira como imagens e textos são relacionados na reportagem da revista.

Ao lado direito da fotografia de Jackson com as crianças, está a legenda "0 ídolo pop e seus fãs: Michael Jackson chega a Salvador na companhia de duas crianças indefesas e foi recebido no Rio de Janeiro por seguranças do Morro Dona Marta”. A relação entre texto e imagem cria uma estranheza, pois ao mesmo tempo em que "crianças indefesas" faz referência às acusações de abuso sexual, os "seguranças do Morro Dona Marta" aparecem na foto logo abaixo, com vários homens sem camisa de braços cruzados.
Os fãs do cantor seriam as crianças que ele abusa e os moradores de favela. Parece ser criada uma ambientação surreal, uma espécie de realidade paralela que precisa existir para que Michael Jackson também exista. 0 texto da reportagem é irônico e crítico, acusando o cantor de vir gravar um clipe em uma favela para desviar a atenção da imprensa de seu divórcio com Lisa Presley e dos processos por abuso sexual. A todo o momento, é reforçado o sentido da loucura e do exótico pelo texto, inclusive chamando Jackson de "gnomo interracial". Na página 34, por exemplo, a revista diz: "Um primor de normalidade, Michael Jackson desembarcou de máscara cirúrgica preta e, como é do seu feitio, apalpando um menino"; já na página 37 , afirma que 0 diretor do videoclipe, 0 
cineasta Spike Lee, não tem muita relação com as esquisitices de Jackson, pois se trata de um homem de respeito, que luta pela igualdade racial: "O que Spike Lee, com esse currículo de militante negro, faz na companhia do descolorido Michael Jackson [...] só o Morro Dona Marta pode explicar. Pelo menos lá, o cineasta está em casa, cercado de personagens que sempre 0 atraíram artisticamente. 0 Morro Dono Marta não é flor que se cheire, ainda mais por alguém que já se exilou numa bolha de oxigênio e tenta proteger-se das impurezas do ar com uma ridícula máscara do Zorro".

A ideia de loucura e fantasia é mais uma vez puxada, agora por comparar os moradores do Dona Marta com os personagens que 0 cineasta (de ficção) Spike Lee cria; e por dizer que Jackson é "descolorido" e "já se exilou em uma bolha de oxigênio", além de usar uma "ridícula máscara do Zorro" (outro personagem ficcional). A representação do cantor nessa edição é bastante diferente das anteriores, pois o foco está todo no exótico, como se Michael Jackson fosse quase um personagem de ficção: não há mais o destaque para seus feitos históricos e seu talento. Resumido a suas excentricidades e seus escândalos, 0 astro é uma caricatura, sem muita importância e objeto de uma mera curiosidade, como uma bizarra atração de circo. Tratado anteriormente como o "outro" que fascina, trazendo um mistério que é atrativo, Michael Jackson transforma-se na diferença que assusta, mostrada de maneira negativa. Essa ambivalência da diferença discutida por Hall, que nunca consegue ser representada de uma única maneira, vai ficar muito clara após a morte do cantor, quando suas diversas representações se misturam criando uma figura híbrida, com sentidos destoantes.

\subsection{0 mito}

Na edição de Veja de $1^{0}$ de julho de 2009, Michael Jackson é uma luva prateada. A revista escolhe como signo para 0 cantor 0 mesmo objeto para o qual chamou a atenção em sua edição de 1984, já demonstrando uma recuperação de sua imagem como "astro total". Assim como naquela edição, em que Jackson brilhava sobre um fundo escuro, a luva também brilha, como uma estrela solitária. Não há manchete, mas apenas MICHAEL JACKSON/1958 - 2009 escrito em branco, de maneira sóbria. 0 destaque bem maior da luva frente ao nome revela 0 sentido preferencial pelo ídolo frente ao homem: Michael Jackson, o ser humano, está morto, mas 0 astro que usava aquela luva, continuará brilhando.

A luva aqui é claramente o que Barthes chama de mito, um objeto revestido de valores que vão para além de suas características próprias. Deixa de ser uma proteção ou enfeite para as mãos e transforma-se naquele mesmo que a usava. Significar Jackson por um objeto retira toda uma dimensão humana, transformando-0 em algo além do ser ordinário. 
Stuart Hall atenta para que pessoas que são significantemente diferentes da maioria são representadas de maneira ambígua, possuindo mais de um significado. Apesar de a representação buscar fixar um significado privilegiado entre os vários potenciais, ele é flutuante e todas as suas formas aparecem como plausíveis. A representação de Michael Jackson na edição de sua morte da revista Veja acaba revelando esse sentido que não consegue se fixar, pois apesar da clara escolha de sentido pela capa, 0 cantor acaba sendo significado de maneiras diferentes, muito em função de suas próprias características pessoais.

Afinal, Jackson possui uma série de significados binários: negro/branco, adulto/criança, homem/ mulher. E isso acaba por interferir em sua representação na revista quando ela busca contar sua morte a partir de uma recuperação de seu passado. A dificuldade em dar um

Figura 8: Capa de Veja, 01 de julho de 2009.

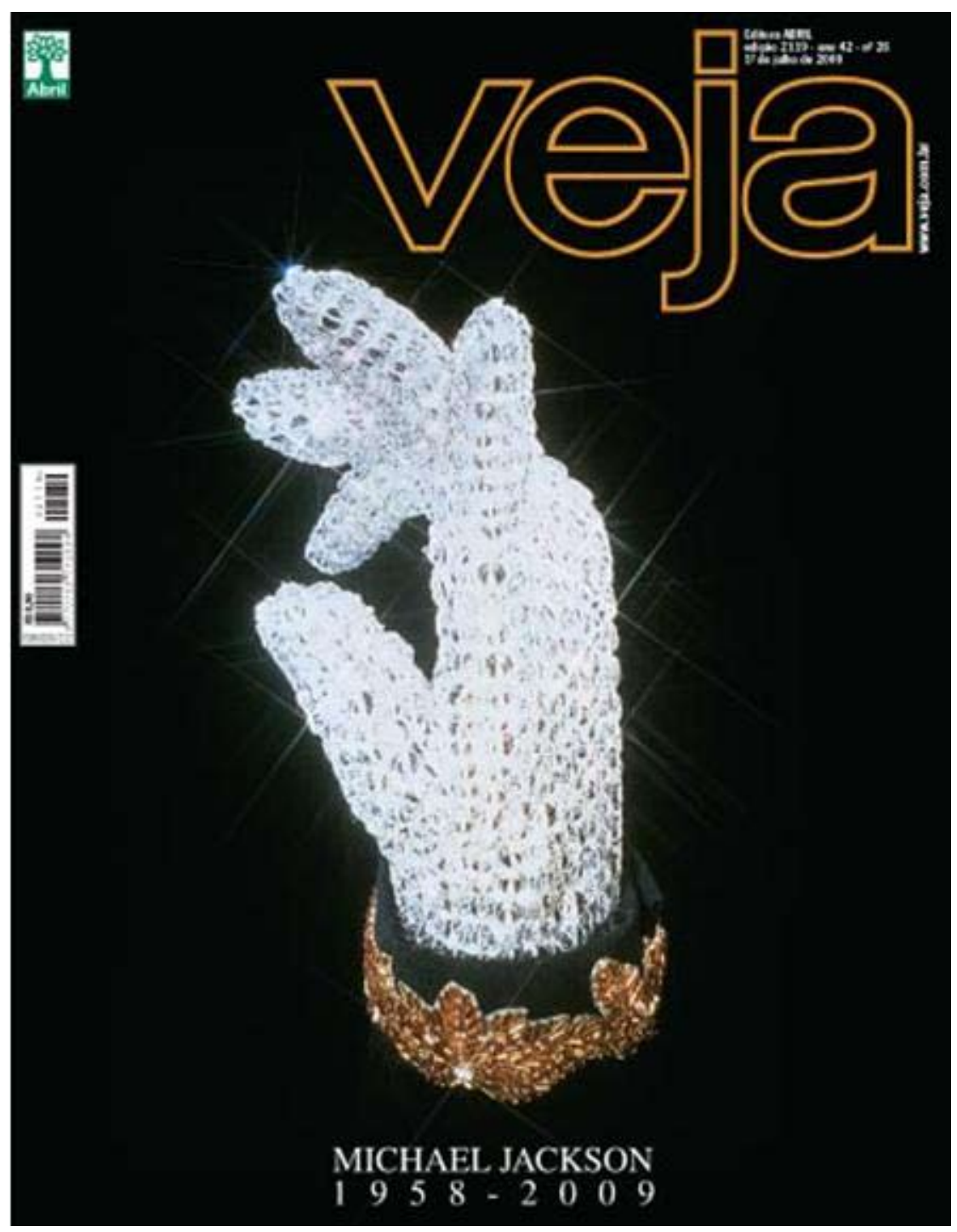


Figura 9: Edição de Veja de 01 de julho de 2009, páginas 96 e 97.

\section{Michael Jackson}

\section{UMA LENDA} ENYOLTA EM MISTERIO, DENTRO DE UM ENIGMA

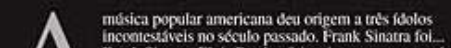

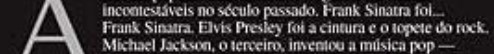
1 Mikhal Jackson, otenceiro, insentos a milsica pop -

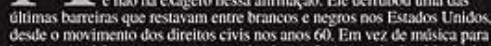
brancose emiska para neyros, agona havia sua fusso revolocionáría de duas tradicos. Jackson clevou fomas de danga das nuss a calceria de ante.

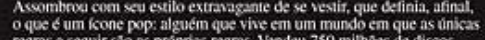

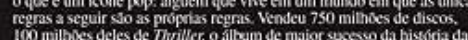

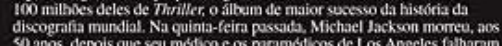
em ressuxitia- lo de uma parnda cardeca. Estava longe dos palcos havia

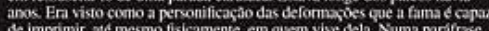

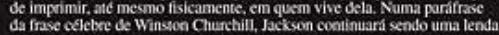
ervolia em mistefio, dentro de un enijgma. No momento des sua monte. contode, voliou a ser o que fol na maior parte da vidat am icone.

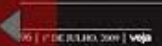

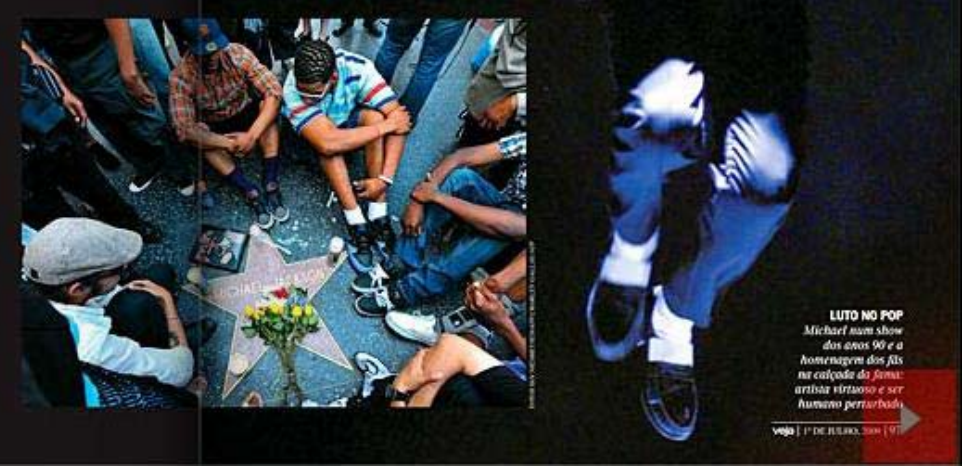

sentido ao astro passa por esses significados que nas edições anteriores apareciam com polos preferenciais, mas que em sua morte aparecem juntos, transmitindo ao mesmo tempo sentidos conflitantes. A matéria principal divide-se em duas partes, já revelando esse caráter dual da representação do cantor.

Na primeira, nomeada "Uma lenda envolta em mistério, dentro de um enigma", Michael Jackson é apresentado como o grande artista, um ser humano especial que revolucionou a música, bastante próximo de sua representação em 1984. 0 texto que abre a matéria reforça a "lenda" do título, colocando seu nome ao lado de grandes referências artísticas: "A música popular americana deu origem a três ídolos incontestáveis no século passado. Frank Sinatra foi... Frank

Sinatra. Elvis Presley foi a cintura e o topete do rock. Michael Jackson, o terceiro, inventou a música pop - e não há exagero nenhum nessa afirmação". Ao lado, uma fotografia de fãs sentados em volta da estrela com seu nome na Calçada da Fama e uma das imagens icônicas do cantor, em passo de dança, com o chapéu e as sombras tapando o rosto.

Mais uma vez Michael Jackson brilha sozinho em um fundo escuro. Sua face escondida mostra o mito suplantando a pessoa, pois 0 foco da reportagem é o ídolo icônico, o homem de chapéu, luvas brancas, jaqueta prateada e sapatilhas pretas. Entre imagens de fãs, da família e do atendimento médico ao cantor, 
destacam-se na reportagem aquelas que mostram 0 artista no auge, seja em shows, videoclipes ou ao lado de personalidades como Nelson Mandela, Diana e Bill Clinton. 0 texto busca recuperar sua trajetória de sucesso, fazendo referência aos seus escândalos apenas no último parágrafo: "Cada vez mais, porém, ia sendo dominado pelo lado obscuramente infantilizado de sua personalidade, que o levaria, a certa altura, a se isolar em sua bizarra propriedade de Neverland - ou Terra do Nunca, em referência ao lugar em que vivia Peter Pan, o garoto que não queria crescer. Esse Jackson aberrante e patético encobriu o totem da revolução pop. Mas, com sua morte, ele renasceu".

Não há, entretanto, referência direta às transformações físicas, acusações de abusos sexuais ou outras características exóticas. Esses outros significados associados a ele parecem ligados aqui ao "mistério" e "enigma" do título da matéria. Nessa representação, Michael Jackson é um super-humano, e suas possíveis falhas são mistérios que ninguém conseguirá explicar, escondidos na sombra de seu mito.

Não por acaso, o outro significado do cantor surge após essa matéria elogiosa, "atrás" do ídolo inventor do pop. Com o título "0 avesso do avesso", a reportagem é mais próxima da representação trabalhada pela revista em 1996. Agora, Michael Jackson é o homem excêntrico, ser bizarro que queria se tornar branco, foi acusado de pedofilia e balançou o filho na sacada de um hotel.

Figura 10: Edição de Veja de 01 de julho de 2009, páginas 106 e 107.

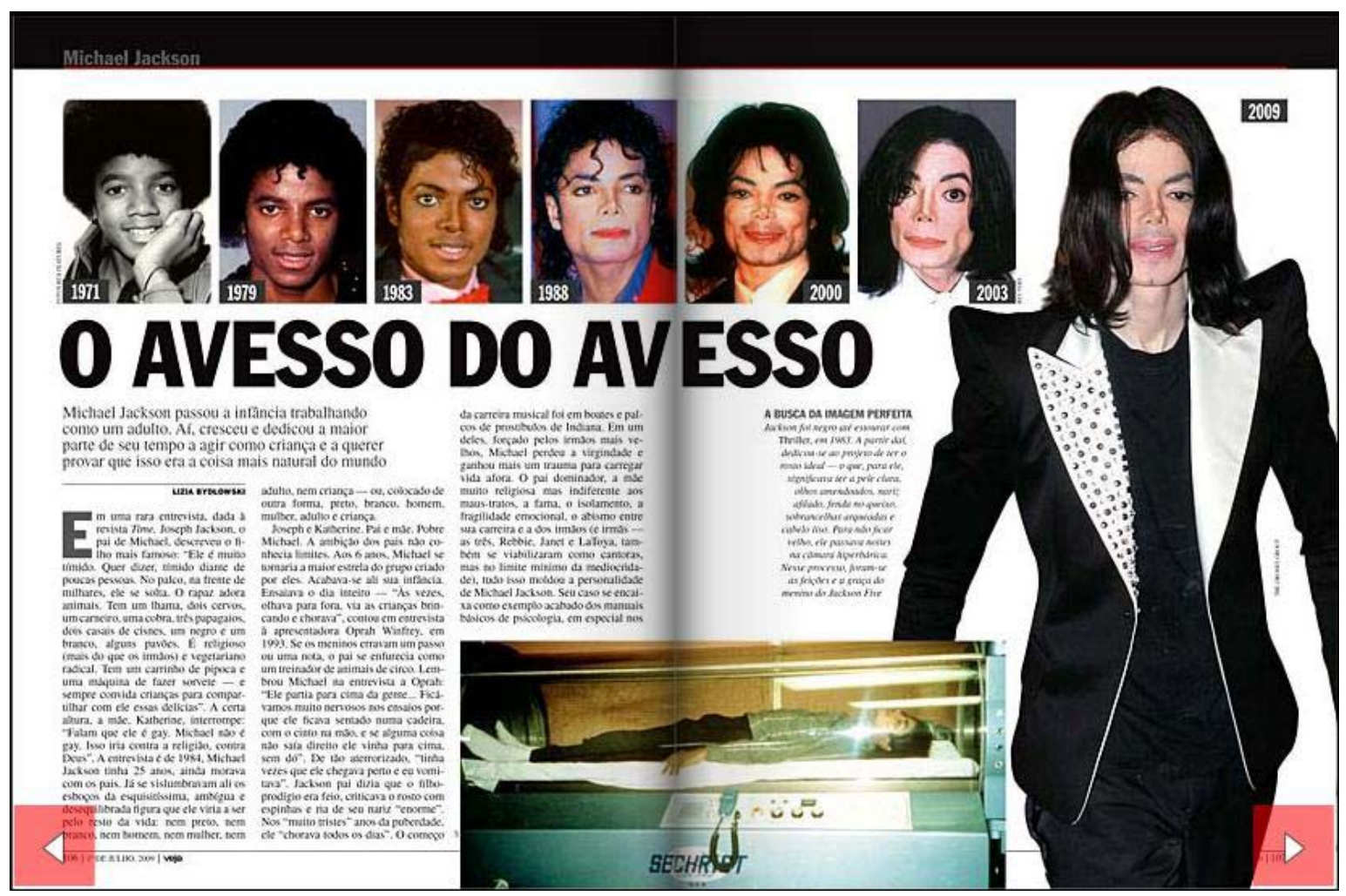


Claramente não há o foco no músico, mas no homem. 0 rosto, evitado na outra matéria, agora domina as duas páginas, em uma espécie de evolução de suas transformaç̧ões físicas, culminando em uma face deformada. Não há nenhum glamour e ele é inclusive mostrado em uma polêmica fotografia onde estaria em uma câmera hiperbárica para não envelhecer (o que, segundo a reportagem, ele nunca admitiu). A ironia reaparece no texto, como ao dizer que Jackson "cresceu e dedicou a maior parte do tempo a agir como criança e a querer provar que isso era a coisa mais natural do mundo". 0 foco está nos escândalos e em suas dívidas, utilizando fotografias dele com crianças e com as esposas, encerrando a matéria dizendo que "as ações e a falta de dinheiro prenunciavam uma velhice atormentada. Michael Jackson escapou de mais esse pesadelo pelo sono eterno".

Interessante perceber como as diferentes representações feitas por Veja ao longo dos anos reaparecem juntas na edição da morte do cantor. Isso porque, apesar de a revista (como detentora da linguagem) possuir a capacidade de escolher um sentido preferencial para atribuir a Jackson, ela está dentro daquilo que Hall chama de circuito da cultura, aberta aos valores da sociedade e, consequentemente, às transformações que Michael Jackson enquanto personalidade pública sofreu através do tempo. Veja atribui, sim, sentido, mas este está voltado ao contexto em que se encontra. Ao tentar contar a história de um cantor que passou por tantas transformações de significados em sua carreira, a revista não consegue escapar de uma representação ambivalente, conflitante até, chegando ao ponto de separar o perfil de Jackson em duas matérias distintas.

\section{Apontamentos finais}

Segundo Hall, a representação conecta significado e linguagem em uma cultura, envolvendo usos de signos e imagens. Trata-se da produção de significados dos conceitos em nossas mentes, permitindo que nos liguemos ao mundo "real" de objetos, pessoas e eventos e também ao imaginário e à ficção.

0 autor aponta a existência de dois sistemas de representação. Primeiro, há o "sistema" pelo qual todo tipo de imagens, pessoas e acontecimentos são correlacionados com uma série de conceitos ou representações mentais que carregamos em nossas mentes. Sem elas, não poderíamos interpretar o mundo significantemente. Em primeiro lugar, então, significado depende do sistema de conceitos e imagens formado em nossos pensamentos que podem substituir ou "representar" o mundo, permitindo-nos fazer referência às coisas tanto dentro como fora de nossas mentes (HALL, 1997, p. 17). 0 outro "sistema" depende da construção de uma série de correspondências entre nosso mapa conceitual e os signos, que são organizados através da linguagem. Da relação entre as coisas, seus conceitos e os signos, nasce o significado, e é o processo responsável pela união desses três elementos que Hall chama de representação. 
Palavras, sons e imagens, mesmo quando exibem semelhança com aquilo a que se referem, continuam sendo signos: carregam significados que precisam ser interpretados. $\mathrm{E}$ para interpretá-los devemos ligar nosso mapa conceitual à linguagem que "traduz" a coisa referida. Mas quando a relação entre 0 signo e seu referente fica menos clara, o significado começa a deslizar, não sendo mais transparente.

Michel Jackson foi uma personalidade repleta de significados conflitantes, e isso se refletiu nas representações midiáticas a seu respeito. 0 artista foi apresentado de diferentes maneiras pela revista Veja durante toda a sua carreira, e essas representações não apenas refletiam a visão da sociedade sobre 0 cantor como também atuavam para 0 compartilhamento desses significados.

Como somos nós que damos significado às coisas (pela relação que estabelecemos entre conceitos e signos organizados pela linguagem), a representação se forma nesse diálogo entre os discursos produzidos e o sistema cultural estabelecido à sua volta. Dessa maneira, em um complexo circuito de formas, valores e ideias, significados são fixados e oferecidos para serem compartilhados e apropriados pelos sujeitos. Nós, que não conhecemos o cantor, temos um sentido associado a ele que passa exclusivamente por essas representações, fazendo com que, para todos nós, Michael Jackson seja essa figura ao mesmo tempo genial, misteriosa, inovadora, assustadora. Cantor e monstro. Homem e mulher.
Adulto e criança. Negro e branco. "Uma lenda envolta em mistério, dentro de um enigma".

\section{Referências}

BARTHES, Rolland . Mitologias Rio de Janeiro: DIFEL, 1978.

FLUSSER, Vilem. Mundo codificado: por uma filosofia do design e da comunicação. São Paulo: Cosac Naify, 2003.

HALL, Stuart. Representation: cultural representations and signifying practices. London: Sage; Thousand Oaks: Open University, 1997.

KELLNER, Douglas. A cultura da mídia. São Paulo: Cultrix, 2003.

MARTINO, Luiz. De qual comunicação estamos falando? In: HOHLFELDT, Antonio; MARTINO, Luiz; FRANÇA, Vera (orgs.). Teorias da Comunicação. Petrópolis: Vozes, 2001.

PEIRCE, Charles. Semiótica. São Paulo:

Perspectiva, 1990.

SANTAELLA, Lúcia; NÖTH, Winfried. Imagem: cognição, semiótica e mídia. São Paulo: Iluminuras, 2005.

SAUSSURE, Ferdinand de. Curso de Linguística Geral. São Paulo: Cultrix, 1997.

SCALZO, Marilia. Jornalismo de revista São Paulo: Contexto, 2004.

SONTAG, Susan. Diante da dor dos outros São Paulo: Cia das letras, 2003.

VEJA. São Paulo: Abril, ed. 828, ano 15, 18 jul.1984. . São Paulo: Abril, ed. 1308, ano 26, n.40, 06 out. 1993. . São Paulo: Abril, ed. 1431, ano 29, n. 07, 14 fev. 1996.

. São Paulo: Abril, ed. 2119, ano 42, n. 26, 01 jul. 2009. 
Who's bad:

Michael Jackson's representations in Veja magazine

\section{Abstract}

This work seeks an application of the representation concept in the transformation of Michael Jackson's figure over the years according to Veja magazine. Representation will be treated the way defined by Stuart Hall, as the connection between meaning and language in a culture, and the magazine will be understood as a place where sense shared in a society are represented. For that, the four magazines which bring the singer in the cover were examined to understand how the words and images reveal values and produce discourses about him.

\section{Keywords}

Representation. Journalism. Magazine.

Michael Jackson.

\section{Who's bad:}

las representaciones de Michael Jackson en la revista Veja

\section{Resumen}

El trabajo busca una aplicación del concepto de representación en la transformación de la figura de Michael Jackson a lo largo de los años a partir de la revista Veja. El concepto de representación será tratado según Stuart Hall, como el encuentro de significados y lenguaje en una cultura, y la revista será percibida como un sitio donde los sentidos compartidos en una sociedad son representados. Para tanto, fueron observadas las cuatro ediciones en las que el cantante apareció en la portada y cómo la escoja de imágenes y palabras revela valores y produce discursos con respecto a él.

\section{Palabras clave}

Representación. Periodismo. Revista.

Michael Jackson. 


\section{Expediente}

A revista E-Compós é a publicação científica em formato eletrônico da Associação Nacional dos Programas de Pós-Graduação em Comunicação (Compós). Lançada em 2004, tem como principal finalidade difundir a produção acadêmica de pesquisadores da área de Comunicação, inseridos em instituições do Brasil e do exterior.

\section{E-COMPÓS I www.e-compos.org.br I E-ISSN 1808-2599}

Revista da Associação Nacional dos Programas de Pós-Graduação em Comunicação. Brasília, v.13, n.1, jan./abr. 2010.

A identificação das edições, a partir de 2008 passa a ser volume anual com três números.

\section{CONSELHO EDITORIAL}

Afonso Albuquerque

Universidade Federal Fluminense, Brasil

Alberto Carlos Augusto Klein

Universidade Estadual de Londrina, Brasil

Alex Fernando Teixeira Primo

Universidade Federal do Rio Grande do Sul, Brasil

Alfredo Vizeu

Universidade Federal de Pernambuco, Brasi

Ana Carolina Damboriarena Escosteguy

Pontifícia Universidade Católica do Rio Grande do Sul, Brasil

Ana Silvia Lopes Davi Médola

Universidade Estadual Paulista, Brasil

André Luiz Martins Lemos

Universidade Federal da Bahia, Brasil

Ângela Freire Prysthon

Universidade Federal de Pernambuco, Brasil

Antônio Fausto Neto

Universidade do Vale do Rio dos Sinos, Brasil

Antonio Carlos Hohlfeldt

Pontifícia Universidade Católica do Rio Grande do Sul, Brasil

Arlindo Ribeiro Machado

Universidade de São Paulo, Brasil

César Geraldo Guimarães

Universidade Federal de Minas Gerais, Brasil

Cristiane Freitas Gutfreind

Pontifícia Universidade Católica do Rio Grande do Sul, Brasil

Denilson Lopes

Universidade Federal do Rio de Janeiro, Brasil

Eduardo Peñuela Cañizal

Universidade Paulista, Brasil

Erick Felinto de Oliveira

Universidade do Estado do Rio de Janeiro, Brasil

Francisco Menezes Martins

Universidade Tuiuti do Paraná, Brasil

Gelson Santana

Universidade Anhembi/Morumbi, Brasil

Goiamérico Felício

Universidade Federal de Goiás, Brasil

Hector Ospina

Universidad de Manizales, Colômbia

Herom Vargas

Universidade Municipal de São Caetano do Sul, Brasil

leda Tucherman

Universidade Federal do Rio de Janeiro, Brasil

Itania Maria Mota Gomes

Universidade Federal da Bahia, Brasil

Janice Caiafa

Universidade Federal do Rio de Janeiro, Brasil

Jeder Silveira Janotti Junior

Universidade Federal da Bahia, Brasil
João Freire Filho

Universidade Federal do Rio de Janeiro, Brasil

John DH Downing

University of Texas at Austin, Estados Unidos

José Luiz Aidar Prado

Pontifícia Universidade Católica de São Paulo, Brasil

José Luiz Warren Jardim Gomes Braga

Universidade do Vale do Rio dos Sinos, Brasil

Juremir Machado da Silva

Pontifícia Universidade Católica do Rio Grande do Sul, Brasil

Lorraine Leu

University of Bristol, Grã-Bretanha

Luiz Claudio Martino

Universidade de Brasília, Brasil

Maria Immacolata Vassallo de Lopes

Universidade de São Paulo, Brasil

Maria Lucia Santaella

Pontifícia Universidade Católica de São Paulo, Brasil

Mauro Pereira Porto

Tulane University, Estados Unidos

Muniz Sodre de Araujo Cabra

Universidade Federal do Rio de Janeiro, Brasil

Nilda Aparecida Jacks

Universidade Federal do Rio Grande do Sul, Brasil

Paulo Roberto Gibaldi Vaz

Universidade Federal do Rio de Janeiro, Brasil

Renato Cordeiro Gomes

Pontifícia Universidade Católica do Rio de Janeiro, Brasil

Ronaldo George Helal

Universidade do Estado do Rio de Janeiro, Brasil

Rosana de Lima Soares

Universidade de São Paulo, Brasil

Rossana Reguillo

Instituto Tecnológico y de Estudios Superiores do Occidente, México

Rousiley Celi Moreira Maia

Universidade Federal de Minas Gerais, Brasil

Samuel Paiva

Universidade Federal de São Carlos, Brasil

Sebastião Albano

Universidade Federal do Rio Grande do Norte, Brasil

Sebastião Carlos de Morais Squirra

Universidade Metodista de São Paulo, Brasil

Simone Maria Andrade Pereira de Sá

Universidade Federal Fluminense, Brasil

Suzete Venturelli

Universidade de Brasília, Brasil

Valério Cruz Brittos

Universidade do Vale do Rio dos Sinos, Brasil

Veneza Mayora Ronsini

Universidade Federal de Santa Maria, Brasil

Vera Regina Veiga França

Universidade Federal de Minas Gerais, Brasil

\section{COMISSÃO EDITORIAL}

Felipe da Costa Trotta I Universidade Federal de Pernambuco, Brasil Rose Melo Rocha I Escola Superior de Propaganda e Marketing, Brasil CONSULTORES AD HOC

João Maia I Universidade do Estado do Rio de Janeiro, Brasil Sandra Gonçalves I Universidade Federal do Rio Grande do Sul, Brasil Mayra Rodrigues Gomes I Universidade de São Paulo, Brasil Gisela Castro I Escola Superior de Propaganda e Marketing, Brasil João Carrascoza I Escola Superior de Propaganda e Marketing, Brasil Luciana Pellin Mielniczuk I Universidade Federal de Santa Maria, Brasil Irene de Araújo Machado I Universidade de São Paulo, Brasil Hermilio Pereira dos Santos Filho I Pontifícia Universidade Católica, Brasil Benjamim Picado I Universidade Federal Fluminense, Brasil Maria Apaecida Baccega I Escola Superior de Propaganda e Marketing, Brasil Rogério Ferraraz I Universidade Anhembi Morumbi, Brasil

Bruno Souza Leal I Universidade Federal de Minas Gerais, Brasi REVISÃO DE TEXTO E TRADUÇÃo I Everton Cardoso EDITORAÇ̃̃ ELETRÔNICA I Roka Estúdio
COMPóS I www.compos.org.br

Associação Nacional dos Programas de Pós-Graduação em Comunicação

Presidente

Itania Maria Mota Gomes

Universidade Federal da Bahia, Brasil

itania@ufba.br

Vice-presidente

Julio Pinto

Pontifícia Universidade Católica de Minas Gerais, Brasil juliopinto@pucminas.br

Secretária-Geral

Ana Carolina Escosteguy

Pontifícia Universidade Católica do Rio Grande do Sul, Brasil carolad@pucrs.br 